\title{
Edward William West and the Pahlavi codex MK
}

\section{ALMUT HINTZE}

\begin{abstract}
This article discusses some manuscripts copied and described by E. W. West in his Notebooks held at the Royal Asiatic Society, with special reference to the texts contained in the Pahlavi codex MK.
\end{abstract}

Keywords: Pahlavi literature; Codex MK; West's notebooks

In the field of Iranian Studies Edward William West (I 824-I905) is well known for his contributions to the study of Zoroastrian literature in Middle Persian (Pahlavi). These include his still valuable survey of Pahlavi literature in the Grundriss der Iranischen Philologie (West I896I904), his translation of the Pahlavi Texts in five volumes in the series The Sacred Books of the East (West I880-I897), and his work on the Arda Wiraf Nāmag in collaboration with Martin Haug (Haug and West I872). What is less known, however, is that he described, copied and collated Zoroastrian manuscripts many of which are no longer accessible. This part of West's - to date unpublished-work is available for consultation in the library of the Royal Asiatic Society (RAS) in London. In I950 Jean de Menasce published a handlist of West's papers at the RAS, grouping them into 70 items, of which the first nineteen had been numbered by West himself as Notebooks I-I9. Little, if any, further work was done on West's papers until the summer of 2018, when Aadityakrishna Satish, an undergraduate from the College of the Atlantic in Bar Harbor, Maine, USA, worked as an intern with the Society and provided a more detailed description of the contents of the notebooks ${ }^{1}$. In 2019 , the RAS's archivist Nancy Charley completed the catalogue and, as a result, a full inventory of West's paper is now available online on the RAS's Archives Hub (https://archiveshub.jisc. ac.uk/data/gb89I-eww). At the time when Aadityakrishna Satish was working at the RAS in the summer of 2018 , members of the Multimedia Yasna (MUYA) team at SOAS, ${ }^{2}$ in

\footnotetext{
${ }^{1}$ A short summary by Aaditya of his work-experience at the Royal Asiatic Society can be found here: https:// royalasiaticsociety.org/a-short-reflection-archive-e-w-west-knowledge/.

${ }^{2}$ The Multimedia Yasna (MUYA) is a project funded by the European Research Council (ERC) with an Advanced Investigator Grant (Principal Investigator: Almut Hintze) 20I6-202I. The research of the present paper was carried out as part of this project. My thanks are due to the ERC for the financial support granted, and to the collaborators named above and other MUYA team members for their help in photographing the Notebooks. I would also like to thank Dan Sheffield for having shared the pdfs of various rare nineteenth-century 
particular Leon Goldman, Céline Redard and Mehrbod Khanizadeh, undertook to photograph notebooks I-36, and in December 2019 Carlo Marchetti and Massimiliano Vassalli (both of the University La Sapienza, Rome) digitised notebooks 37-55 in collaboration with SOAS students, including Ruzbeh Hodiwala and members of the MUYA team. The images have been made available to the Royal Asiatic Society for eventual online publication. In what follows I propose to discuss manuscripts copied and described by West in his notebooks, with special reference to the texts contained in the Pahlavi codex MK. ${ }^{3}$ I am delighted to dedicate this article to François de Blois, who has spent a good part of his career at the Royal Asiatic Society as a Research Fellow working on his invaluable Bio-Bibliographical Survey of Persian Literature. I have always valued and admired his work as that of a great, and rare, scholar whose expertise spans both Iranian and Semitic language sources.

Born as the eldest of twelve children into a family of architects and engineers on the paternal side, E.W. West studied Engineering at King's College, London (I839-I842). His father owned several cotton presses in India, and West spent the years I844-I85I, I852-I866 and I $874-1876$ in India, first superintending the family-owned cotton presses in Bombay and, from I 852, as Chief Engineer on the Great Indian Peninsular Railway Project. In preparation for his first trip he studied Hindustani for a few weeks under Professor Duncan Forbes of King's College, London and learned the Perso-Arabic and Nagari scripts. Otherwise his knowledge of foreign languages was self-taught. In Bombay, West made the acquaintance of many Parsis. It was a Parsi who managed the family cotton presses, and occasional conversations with him drew West's attention to the Zoroastrian religion. ${ }^{4}$ West read Martin Haug's Essays on the Sacred Language, Writings, and Religion of the Parsees, first published in I862, and their personal encounter in Poona in I 866 led to a life-long friendship not only with Haug but also with leading Zoroastrian priests and scholars, in particular with Dastur Hošang Jāmāspji Āsā in Poona, with Dastur Peshotan Behram Sanjana and his son Dārāb Dastur Peshotan Sanjana in Bombay, and, especially, with Dastur Jāmāspji JāmāspĀsāna in Bombay.

\section{West's copy of MK (I875)}

During his third visit to India in I $874-1876$ West spent a good amount of his time studying Zoroastrian ancient texts and manuscripts. It was in that period that he copied a considerable number of Pahlavi manuscripts. Among them was the Pahlavi codex MK of the collection of Dastur Jāmāspji JamaspĀsāna, who greatly treasured this particular manuscript. West made his copy in 1875 , and it is preserved on pp. I-99 of his Notebook (NB) I 3 at the RAS. In his notebooks, West used the siglum DJ (for Dastur Jāmāspji) for this manuscript, ${ }^{5}$ while JamaspĀsāna I9I3 refers to it as MK after the initials of the scribe Mehrabān

publications, and Edward Weech, Nancy Charley and Alison Ohta of the RAS for making West's notebooks and papers available, for facilitating our work at the RAS, and for the permission to reproduce some of the images here.

${ }^{3}$ The long-awaited facsimile edition of the manuscript MK, prepared by its late owner Kaikhusroo M. JamaspAsa and myself, is scheduled to appear in the series Iranica in 2022.

${ }^{4}$ For a description of West's life, see the article by A.V.W. Jackson, revised by J. B. Katz 2004, in the Oxford National Biography. Rich, and to date almost entirely unexplored, primary source material on the activities of E.W. West and his brothers in India is available both at the RAS and in the British Library.

${ }^{5}$ In his publications, West uses the siglum "J", e.g. in his detailed survey of the contents of MK in West I $896-$ I904, pp. III-II6. 
Kayhusraw, who copied it in I 322 CE. The manuscript contains 38 texts which belong to different literary genres, including Wisdom (Handarz) and Court literature.

The significance of MK lies not only in the fact that it is the oldest extant Pahlavi manuscript, and thus the oldest extant witness for any of the texts it contains, but also that seven of them are only known from this manuscript and its transcripts. ${ }^{6}$ These are Ayādgār $\bar{\imath}$ Zarēeran 'Memorial of Zarēr' (MK Text I), Šahrestānīhā ì Ērān 'The cities of Ērān' (MK Text 2), Abdīh ud sahīgīh $\bar{\imath}$ Sèstān 'The marvel and worthiness of Sīstān' (Text 3), Husraw ì Kawādān ud $\overline{r e} d a k-\bar{e}$ 'Husraw, son of Kawād, and a page' (MK Text 4), Handarz ì dānāgān ō mazdēsnān 'Advice of the Wise to the Mazdayasnians' (MK Text 6), Handarz $\overline{1}$ Husraw $\overline{1}$ Kawādān 'Advice of Husraw, son of Kawād' (MK Text 7) and Wāzagīhā $\bar{\imath}$ Baxtāfrīd ud A $\overline{d u r b a \bar{d}} \bar{\imath}$ Zarduštān 'Sayings of Baxtāfrīd and of Ādurbād, son of Zardušt' (MK Text I 8).

On a loose sheet enclosed in Notebook I 3 after p. I44, West describes the manuscript MK and provides insights into its state of preservation in his time, as follows:

Pahlavi Shahnamah Ms. (D.J.) in the library of Dastur Jamaspji Minochiharji Jamaspasana, I 42 folios of old brownish Indian paper, $9^{\prime \prime} \times 5^{1 / 2}$ " written I 4 lines to the page, on the first I Io folios and I 4 to 22 lines on the rest, ${ }^{7}$ clear and distinct where not eaten away by the white ants; has been bound but the folios are now loose and easily displaced, the sewing being eaten away. The folios have no catch words and are only numbered with a lighter ink (and probably at a later date) at the bottom right hand corner on the $\mathrm{b}$ page in Gujarati figures; these figures indicate the loss of some folios, the missing I 8 folios being N. 63, 66, 68, I I $2-\mathrm{I} 25$, and I40; the last fol. being N. I60.

West's number I 8 of the missing folios diverges from the number 2 I given by Anklesaria I9I 3 , p. I only because West omits from his count folio o at the beginning of the manuscript and fols. I6I-I62 at the end. The number of folios missing then was actually the same as it is today. What West refers to as fol. I40 is wrongly marked and is in fact fol. I37, as noted by Anklesaria. On the same loose sheet, West goes on to explain his method of marking lacunae or restorations in his transcription of MK:

In the copy, all letters more or less eaten away are underlined with pencil; when they are absolutely certain they are written in ink, if more or less uncertain in pencil (but these include all letters certain but of which no traces remain, or which are not absolutely indispensable). When the letters are very uncertain the space above the pencil line is left blank. - Every page is collated, after writing, with the original. Glosses in different ink, and therefore presumably by a later hand, are written here in pencil. Words struck out (by overpoints, or otherwise) in the original MS. are omitted in this copy, but blunders unaltered in the original MS. are copied as they stand, and often indicated by sic to show that they are in the original. ${ }^{8}$

The rigorous precision with which West executed the copying of MK and of other manuscripts is characteristic of his work preserved in the Notebooks. His diligence is particularly valuable, well suited to documenting the lacunose state of preservation of MK. In fact, the poor physical condition of MK even in West's time led Anklesaria I9I 3, 2 to comment that the copies of MK and of any other witnesses of the texts MK contains, are essential to fill the many gaps in MK.

\footnotetext{
${ }^{6}$ Haug I 878 , pp. I09-I Iо.

${ }^{7}$ It is in fact from MK's fol. I28v that the lines per page are more than I4.

${ }^{8}$ West's note enclosed in Notebook I 3 after p.I 44.
} 


\section{The manuscript JJ (I767) and its copy T (ca. I850?)}

The most important copy of MK, the manuscript JJ, was transcribed by Dastur Jamšêd JāmāspĀsāna, whose initials provide the siglum of this ms. Anklesaria I9I3, 8 notes that at the time $\mathrm{JJ}$ was copied the I4 folios II2-I25, which included an entire quire, and the two folios I6I-I62 of MK were still present, because the texts they contain are transcribed in JJ. However, MK's four fols. 63, 66, 68 and I37 (wrongly marked I40) were already missing. In JJ the gaps of text due to the absence of these four folios are not indicated, the preceding and following folios being copied continuously. ${ }^{9}$

In various places both in his Notebooks and in print, West states that JJ was copied in the year I 72 I of the Christian era. ${ }^{10}$ This date is based on the assumption that JJ was completed in I090 of the Yazdegird era (AY). The year I090 is written above the line in West's description of Dasturj Jāmāspi's copy (T) of JJ in Notebook 3, p. 227, where the colophon in Persian of JJ is copied. West also gives this date in the draft of a note, which would have accompanied the copy he made for Dastur Jāmāspi of some of the texts in Notebook I3 (Fig. I):

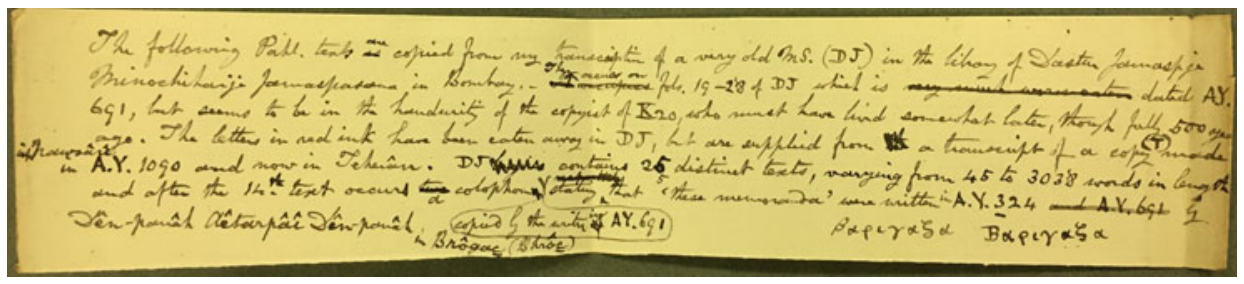

Figure I. Note by West giving the date of the ms. JJ as AY I090 (I72 I CE) on a loose piece of paper inserted in NB I 3 after p.20.

The following Pahl. texts are copied from my transcription of a very old MS. (DJ) in the library of Dastur Jamaspj Minochiharji Jamaspasana in Bombay. They occur on fols. I9-28 $8^{11}$ of DJ which is dated AY 69I, but seems to be in the handwriting of the copyist of K20, who must have lived somewhat later, though fully 500 years ago. The letters in red ink have been eaten away in DJ, but are supplied from a transcript of a copy (T) made in Nawsâri in A.Y. IOgO and now in Teherân. DJ contains 25 distinct texts, varying from 45 to 3038 words in length and after the $14^{\text {th }}$ text occurs a colophon copied by the writer in A.Y. 69I stating that 'these memoranda' were written in A.Y. 324 by Dên-panâh Aêtarpâî Dên-panâh in Brôgac (Bhrôc).

At the time West wrote this note, the original ms. JJ was in Tehran. JJ had been taken there by its then owner Manekji Limji Hataria, who was a keen collector of Zoroastrian manuscripts. According to West's I887, 264 and fn. 3 account of the history of JJ, Manekji Limji Hataria acquired the manuscript JJ in Mumbai "il y a à peu près 35 ans". This would have been around I852. In I 854, Manekji was sent to Iran as the first emissary of the Society for the Amelioration of the Condition of Zoroastrians in Persia, and it was

9JamaspĀsāna I9I3, 68 n.60, 72 n.I, 74 n.I, I27, n.8.

${ }^{10}$ E.g. West I 887,264 and I $896-$ I904, p. III.

${ }^{11}$ The texts West refers to are Šahrestāninhà $\bar{i}$ Erān (MK fols. I9v5-26r6, West NB I 3, 20.I I-25.20) and Abdīh ud sahīgìh ì Sìstān (MK fols. 26r7-28r4, West NB I3, 26.I-27.I3). 
presumably at that time that that he took JJ to Tehran. After Manekji's death on I 5 February I 890, his library was bequeathed to the Parsi Community, and with it JJ came back to India. In a note on the bottom margin of p. 8 of Notebook I3, West records the presence of JJ in Bombay in July I89I (Fig. 2):

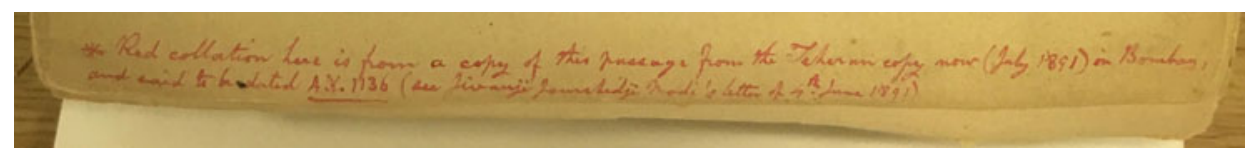

Figure 2. West, Notebook I3, p.8 bottom margin

Red collation here is from a copy of this passage from the Tehran copy now (July I 89I) in Bombay and said to be dated A.Y. I 36 (see Jivanji Jamshedji Modi's letter of 4th June I89I).

The note indicates that West now dates the ms. JJ to AY I I 36 on the basis of a letter of 4 June I 89 I by J.J. Modi. This correction was presumably possible because the original manuscript had by then returned to Mumbai and was again available for consultation. While working on his Introduction to JamaspĀsāna's Pahlavi Texts, Anklesaria I9I 3, 8-Io must have been able to consult the original manuscript $\mathrm{JJ}$ as he reproduces its colophons, which state that JJ was completed on day Hormazd, month Shahrewar AY II 36 ( $={ }_{1} 6^{\text {th }}$ March 1767 CE).

The manuscript JJ then came into the possession of the Trustees of the "New Atash Behram" in Bombay. ${ }^{12}$ The "New Atash Behram" was established under the leadership of Dastur Jāmāspji on I7 October I897 and named Anjuman Ateš Bahram. ${ }^{13}$ Around I930 the Hataria collection was transferred from there to the K. R. Cama Oriental Institute, Bombay, as recorded in the Annual Report for the year I930 of the Cama Oriental Institute: ${ }^{14}$

Manekji Limji Hateria Library. —As stated in the report for the year $1929,{ }^{15}$ arrangements were made, by securing the order of the High Court, to transfer the above Library from the Anjuman Atash-behram to this Institute. The books and Mss., as selected by Prof. N. D. Minocherhomji and brought to this Institute, numbered as under:

Avesta, Pahlavi and other books relating to Zoroastrianism........38

Mss. on the same subjects .................................28

Books on miscellaneous subjects............................ I I I

Persian books and Mss. .................................... 923

Total $\ldots . . . \ldots \ldots \ldots \ldots$. I, I 20

${ }^{12}$ Anklesaria I9I3, 8. Similarly, Geldner I896, xi fn. I notes that the Avestan mss. Mli-4 of the collection of Manekji Limji Hataria have been "in the hands of a committee in Bombay" since Manekji's death. Of these, the manuscript 46I5_Ml3, a Pahlavi Vidēvdād dated I 595 CE, is now kept in the Rare Book and Manuscript Library, Columbia University, USA, where it is catalogued with the shelfmark X892.5 Av3 S2. Digital images of $\mathrm{Ml}_{3}$ were published by Miguel Ángel Andrés-Toledo on the website of the Avestan Digital Archive.

${ }^{13}$ Anklesaria I9I3, p. 62.

${ }^{14}$ The K. R. Cama Oriental Institute Report for the year I930. Journal of the Cama Oriental Institute I9, I93 I, I78-I79. I am grateful to Dan Sheffield for drawing my attention to this source.

${ }^{15}$ According to the report of 1929 (Journal of the Cama Oriental Institute I7, I930, 98), an approach was made by Dr N. N. Katrak on behalf of the Bhagarsath Anjuman Atashbehram to hand over to the Cama Oriental Institute the Manekji Limji Hateria Library along with the fund of Rs. 5,000 belonging to the Hateria Library and six cupboards. 
The ms. JJ could well have been among the mss. transferred to the COI, but unfortunately to date it has not been possible to locate it either there or anywhere else.

By the time JJ was returned to Bombay in I89I, West was living in England, and he never saw the original manuscript. What he used for his collations was a copy of JJ made by Dastur Jāmāspji, who must have copied JJ before it was taken to Tehran. In his Notebooks, West refers to this copy as $\mathrm{T}$ (for Tehran). West I 887, 264 mentions that Dastur Jāmāspji lent him his copy of JJ (i.e. T) in I 877 in order to fill the gaps in his own transcription of MK of I $875 .{ }^{16}$ Since West returned to Europe in I 876 , Dastur Jāmāspji must have sent his copy of JJ to West by mail or in some other way. It seems that upon completion of his work West sent the ms. T back to Bombay because Darab Dastur Peshotan Sanjana I896, pp. $\mathrm{xxx}-\mathrm{xxxii}$ seems to describe this manuscript, referring to it as "J", although he did not collate it in his edition of the Kärnāmag. That Sanjana's "J" is not MK itself but a copy of it emerges clearly from the fact that Sanjana describes MK's second colophon, which is of Mihrābān Kayhusraw, as that "of the original codex from which J. is derived". Moreover, he provides the text of the Sanskrit colophon, which is lost in MK but present in JJ. Since JJ was available again in Bombay from I89I, Sanjana's "J" could be that ms. However, Anklesaria I9I 3, 8 informs us that JJ is written I6-I 8 lines per page and has I 72 folios while Sanjana's description differs slightly from JJ in that his "J" has 347 pages (= I74 folios) written I2 lines to a page. These details perfectly agree with those provided by West, Notebook 3, p. 227 for Dastur Jāmāspi"s copy of JJ, for which West uses the siglum T: "T is a manuscript of 347 pages, $7 \frac{3}{4}$ " high $\times 6$ " wide, written I 2 lines to a page."

The present location of Dastur Jāmāspji's copy (T) being unknown, all we currently have are the readings of $\mathrm{T}$ given by West in his Notebooks, alongside those of JJ provided by JamaspĀsāna I9I3. For when Dastur Jāmāspji began his work on the edition of his Pahlavi texts in I896 (Anklesaria I9I3, p. I), he would have had access to the original ms. JJ.

\section{West's copy (W) of texts copied in Notebook I3 (I890)}

In I890, while living in Munich, Germany, West copied his own I875 copy of MK, preserved in Notebook I3, for Dastur Jāmāspji in order to aid the latter in his editorial work. The draft of a cover note by West has survived on a loose sheet following p. 20 of his Notebook I3. It is dated Munich, March I 890 and was meant to accompany the copy West made for Dastur Jāmāspji. The note states (Fig. 3)

(Heading of a copy made for Dastûr Jâmâspji)

The following Pahlavi text is transcribed from a copy of Dastur Jâmâspji's old MS (called Vishtâsp-shâh-nâmak) made in I875. The letters written in blue ink are eaten away in the old MS., and were supplied by guess in the copy of $\mathrm{I} 875$, but have since been confirmed by comparison with a copy of a transcript made by Jamshêd Jâmâspâsâ in I72I, and belonging to Mânekji Limji of Teherân. The letters interlined in red ink are given from the copy of the transcript of I72I, where they could not be guessed in I875, on where that copy differs from the guess

\footnotetext{
${ }^{16}$ West I 887 , pp. $264-265$ writes: "Il y a onze ans Dastûr Jâmâspji a bien voulu me permettre de copier son ancien manuscript de $\mathrm{I} 322$, et deux ans plus tard il me prêta une copie qu'il avait faite sur celle de Téhéran pour remplir les lacunes qui existent dans son ancient codex."
} 


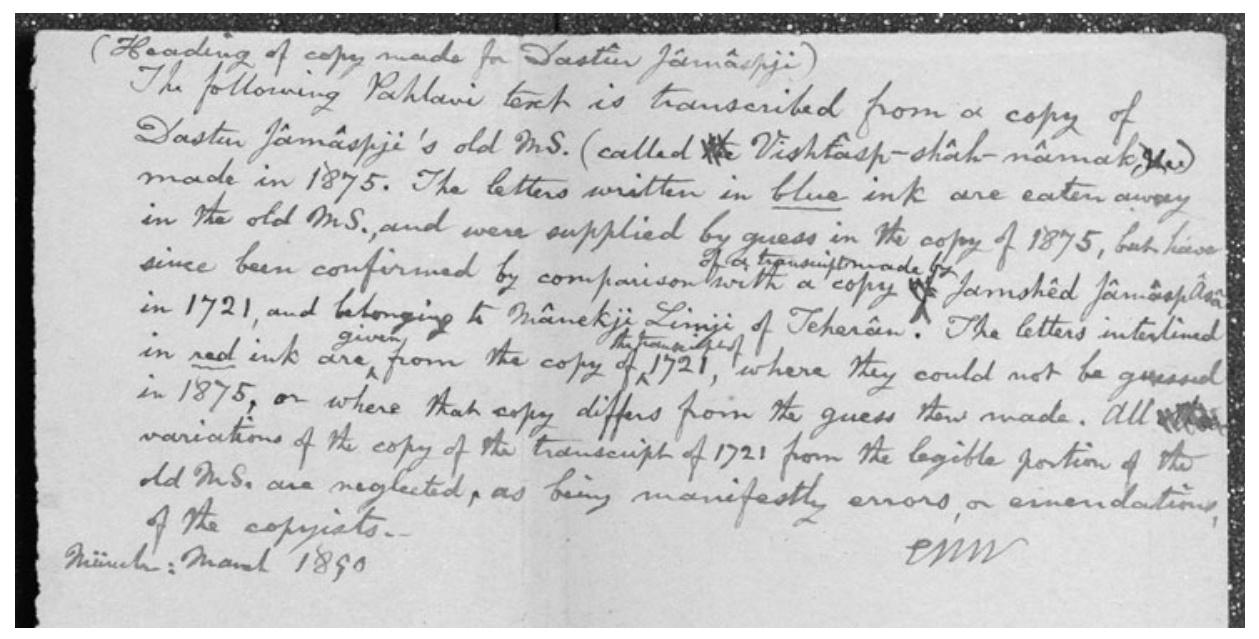

Figure 3. Draft of the cover note of the copy which West made in I 890 for Dastur Jāmāspji of his own transcription of MK of I 875 . The note is inserted after p.20 in West's Notebook I 3 at the Royal Asiatic Society, London.

then made. All variations of the copy of the transcript of I72I from the legible portion of the old MS. are neglected, as being manifestly errors, or emendations, of the copyists.

München, March I890. EWW

Although West explicitly made the transcript of his copy for Dastur Jāmāspji, Anklesaria I9I3, p. Io, informs us that West sent the copy to his father, Ervad Tehmuras Dinshaji Anklesaria "for facilitating Dastûr Jamaspji's work." In his edition of the Pahlavi texts, JamaspĀsāna I9I 3 uses the siglum W to refer to West's copy of I890. The latter is now kept in the library of the Cama Oriental Institute, Mumbai under the signature Khata 4. According to Sheffield's description, the volume has 68 pages and includes "various texts" of MK, starting with Text I, the Ayādgār i Zarērān. ${ }^{17}$

Anklesaria I9I3, p. I I, reports that West did not send copies of MK's Text 5 Čidag handarz $\bar{\imath}$ pōryōtkēšān (= Pand nāmag $\bar{\imath}$ Zardušt, PT pp. 4I-50), Text 6 Handarz $\bar{\imath}$ dānāgān $\bar{o}$ mazdēsnān (PT pp. 5I-54), Text 7 Handarz $\bar{\imath}$ Husraw ì Kawādān (PT pp. 55-57), Text 24 Ayādgār $\bar{\imath}$ Wuzurgmihr (PT pp. 85-IOI), Text 27 Wizārišn $\bar{\imath}$ čatrang ud nihišn $\bar{\imath}$ nēw-ardaxš̀r (PT pp. II5-I20), because editions of these five texts had been published by Peshotan Behram Sanjana in I885. Nor did West provide a transcription of the Kärnāmag, a text which is also absent from West's copy of MK of I875. Notebook I3, p. 60 only provides a note stating that the Kârnāmag covers fol. 75 r2 to fol. I08r7 of the codex MK. Accordingly, JamaspĀsāna I9I 3 provides no readings reported by West for any of these six texts. The fact that the first five of them are present in West's notebooks further confirms that JamaspĀsanna was working with West's copy of I 890 , which West copied from his own transcription of MK of I 875, preserved in his Notebook I3. JamaspAsa's edition of I9I 3 omits the Kārnāmag on the grounds that Ervad Edalji Kersaspji Antia used MK for his edition of the text,

\footnotetext{
${ }^{17}$ Sheffield 2009, 20.
} 
published in I900. Moreover, at the time Dastur Peshotan's son Darab Peshotan Sanjana was also working on an edition the Kārnāmag, published it in I $896 .{ }^{18}$ However, Sanjana collated neither MK nor its copies JJ or T, although he describes the latter, referring to it as "J" (see above section 2).

\section{The ms. DP (ca. I350-1390?)}

Like Dastur Jāmāspji, Dastur Peshotanji Behramji Sanjana (I828-I898), too, owned a remarkable collection of manuscripts, which he passed on to his son Darab Peshotan Sanjana (I857-I93 I). After the death of the latter, the manuscripts together with the printed books of the Sanjana collection were presented to the Cama Oriental Institute in I933. ${ }^{19}$ Among the manuscripts of the Sanjana collection was the codex DP containing texts also found in MK, but in the absence of a catalogue it is difficult to verify whether the codex DP was among the six manuscripts recorded to have been donated to the Cama Oriental Institute in 1933 .

Referring to DP with the siglum Pt, West I896-I904, pp. I IO-I I I, surveys the contents, and in Notebook I3, p. IOI he provides the following physical description of the manuscript, which was bound in an unusual way:

MS. D.P. belonging to the library of Dastur Peshotanji Behramji Sanjana. Pahlavi Jāmāsp nāmak, etc., 75 folios remaining out of I63 numbered, of old brownish Indian paper, $7^{\frac{1}{2}}$ " $\times 4^{\frac{1}{2} 2}$ ", written I 4 to 17 lines to a page; folios generally uninjured, excepting some of the earlier ones.

It has been written not to bind up as a book, but for each folio to be reversed separately whilst reading, so that the writing on one page is upside down to that on the other, and the folios appear to have been connected at the top in pairs, at least fols. IOO + IOI are so connected, so that after reading Iooa you turn it up from the bottom and then have Ioob and Iora before you ready for reading one below the other, and then turning up iora from the bottom you have Iorb similarly before you. - The folios are numbered in the centre of the top margin on the b side in Gujarati figures; this numbering extends up to I63, but the following 88 folios are missing: I to I6, 20 to 26, 32 to 73,79 to 99 , and I62; it seems likely also that some folios were missing before these numbers were written, as between fols. I $32+$ I 33 .

West I887, 264 describes DP as "un manuscrit vraiment ancien" and as one with no date. ${ }^{20}$ According to Sanjana I 885, English preface p. iv, DP was copied by Ervad Kāmdīn Shehryār Nēryosangh Samand from a manuscript which was completed by "a chief Peshwa of our religion" at Bharuch on day Gōš, month Ardibehešt in the Samvat year Io67 (= Io I I CE.) for the use of a pupil named Šāhzād, son of Šād. West I887, 264 notes that Kamdīn's son Rām copied a manuscript dated I4IO CE, and Peshotan, the son of Rām and grandson of Kamdīn, copied a further manuscript in I 397 CE. The latter is the miscellaneous codex M6 (Cod.Zend 5I) obtained by Martin Haug in Surat in I864 and now kept in the State Library

\footnotetext{
${ }^{18}$ Anklesaria I9I3, 32.

${ }^{19}$ The Annual Report for I933 (Journal of the Cama Oriental Institute 27, I934, I67) records a donation of six mss. and 59 books from the library of Dastur Darab S. Sanjana by his daughter, Mrs Ratanbai C. Badshah.

${ }^{20}$ Haug I872, p. I08, too, refers to DP as a "very old manuscript in Dastur Peshotanji's library in Bombay".
} 
of München. ${ }^{21}$ On the basis of this data, West estimates that DP was copied between I 350 and $\mathrm{I} 390 \mathrm{CE} .^{22}$

The details of the place and beneficiary given by Sanjana for Kāmdīn's original agree with those in col. 2 of MK fol. $74 \mathrm{r}_{4}-5 .{ }^{23}$ The latter colophon belongs to the Ioth-century manuscript of Dēn Panāh, the source manuscript from which the Texts 2-I9 (and probably also Text I, the Ayādgār ì Zarèrān) of MK were transcribed. However, the date AY 324 (956 CE) of MK's colophon 2 is different from the year Samvat IO67 (IO I CE), which Sanjana gives for the completion of Kāmdīn's original. Regardless of this discrepancy, it appears that DP derives not from $\mathrm{MK}$, as almost all other copies do, but is an independent transcript of the source manuscript from which Texts I-I9 of MK ultimately also descend. François de Blois 2000, p. 88 already noted this when commenting that neither MK nor DP is copied from the other but they both descend from a common source.

During his third stay in India, in I 876, West fully transcribed those parts of DP which are either not included in MK (Ayādgār $\bar{\imath}$ Jāmāspīg) or which were lost in MK at his time (MK Text 25 Māh $\bar{\imath}$ Frawardīn Rōz $\bar{\imath}$ Hordād, and MK Text 29 Mādayān $\bar{\imath}$ sīh rōzag). West's transcription of these three texts of DP are preserved in Notebook I3, pp. IOI-I I2, ${ }^{24}$ where West also surveys the other texts of DP which he did not transcribe but only collate with his transcriptions of other manuscripts, including MK.

The ms. DP has been noted as being a very rare witness of the Pahlavi version of the Ayādgār $\bar{\imath}$ Jāmāspīg (or: Jāmāsp Nāmag). ${ }^{25}$ The typeset text of DP's folios I7-I9 (AJ IO.I-I2.9) and fols. 27-3 I (AJ I6.4-43) of the Ayāadgār $\bar{\imath}$ Jāmāsppig is reproduced in West I904 and then again in Agostini 20I3, pp. 367-375. West's edition provides the text in the Pahlavi script "so far as it was extant in I 876 in a very old Manuscript belonging to the late Shams-ul-Ulama Dastur Dr. Peshotanji Behramji Sanjana” (West I904, p. 97). That the typeset Pahlavi text he reproduced in the publication of 1904 is based on the transcription he made in 1876 , and which is preserved in Notebook I3, pp. I02-I09, is confirmed by the fact that the typeset text of DP published in 1904 includes words restored by West in his Notebook from the Pāzand version to fill gaps in the manuscript DP (Fig. 4).

West also collated the remaining texts of DP with those which are preserved in MK, providing the readings of the former in his transcription of the latter. That JamaspĀsāna I9I 3 worked with West's copy of the manuscript DP rather than with the original emerges from Anklesaria I9I3, I I, who informs us that the variants of DP and of five other manuscripts "were all kindly supplied by Dr West, but for which the texts would have been very imperfect". A case in point are $\iint_{117-\mathrm{I} 32}$ of the Handarz $\bar{\imath}$ anōšag-ruwān $\bar{A} d u r b \bar{a} d \bar{\imath}$ Māraspandān (Hand.Ādur.Mār., MK Text I2), which are lost in MK due to the loss of its folio 63. In his edition of the Pahlavi Texts, JamaspĀsāna, who on this occasion refers to $\mathrm{DP}$ as $\mathrm{W}$, states that he has taken the text of these paragraphs "solely from $\mathrm{W}$ ", ${ }^{26}$ that is

\footnotetext{
${ }^{21}$ West I896-I904, p. 98. The contents of M6 are surveyed by Haug and West I872, iii-v, and described in detail by Bartholomae I9I 5, pp. 38-72.

${ }^{22}$ West I 887 , p. 264; I896-I904, p. I Io and I904, p. 97 fn.I.

${ }^{23}$ JamaspĀsāna I9I 3, p. 83 .

${ }^{24}$ De Menasce I950, p. 56.

${ }^{25}$ On the manuscripts of the Pahlavi version of this text, see Agostini 20I3, pp. 6-9.

${ }^{26}$ JamaspĀsāna I9I 3, p. 69 fn.67.
} 


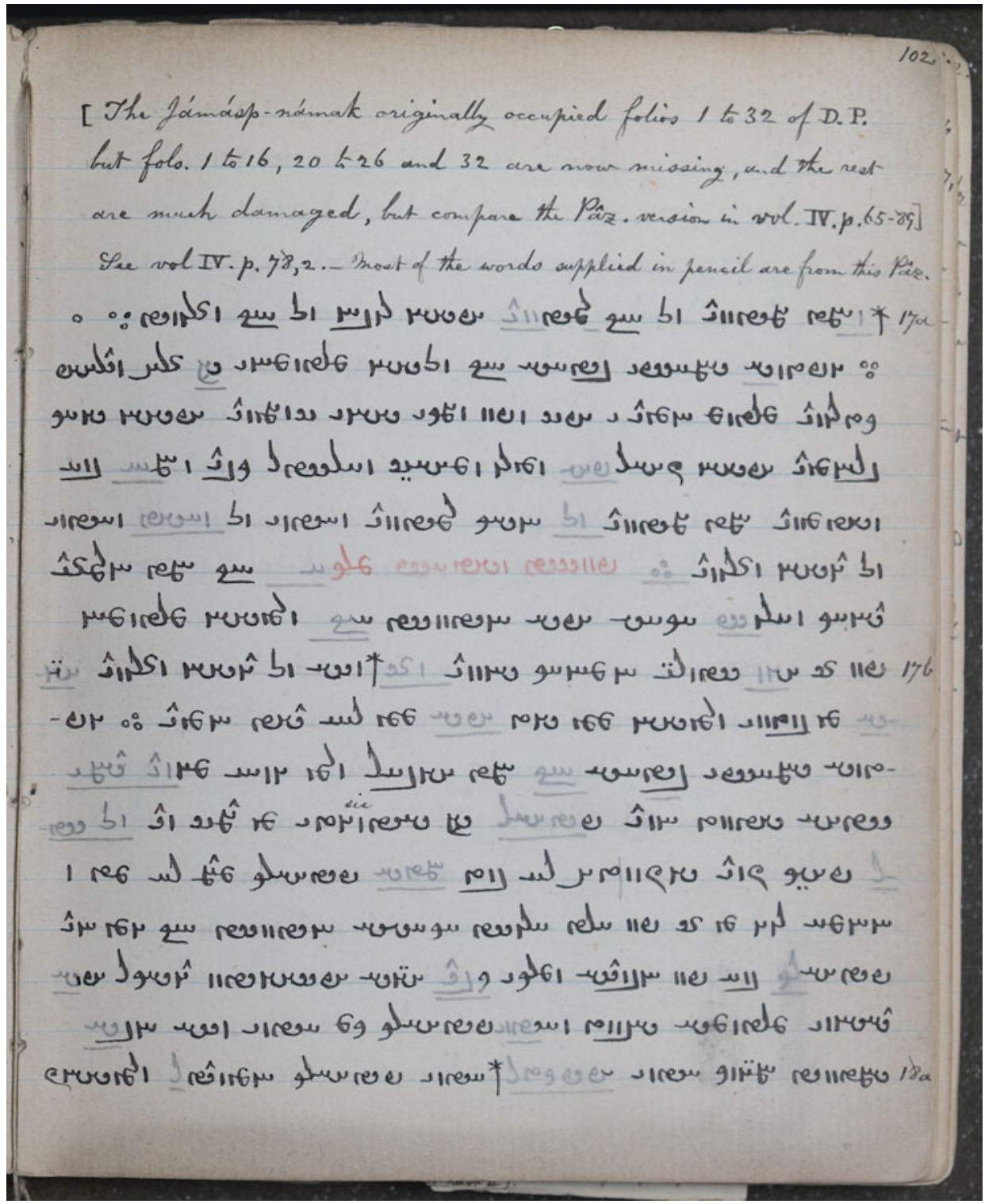

Figure 4. Beginning of West's transcription of the ms. DP Notebook I3, p.IO2.

from West's transcript of I890, discussed above in section 3, of his copy of MK of 1875 . While JamaspĀsāna I9I3, p. 69 edits the text of SS I I 7-I 32 of this Handarz, West, Notebook

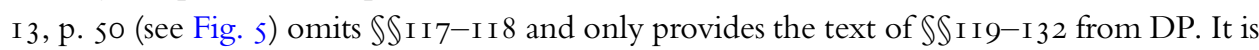
unknown where JamaspĀsāna took the text of $\iint_{\text {II }}$ 7-I I 8 from.

Much of the text of MK's lost folio 63 has thus been retrieved from DP through West's copy of this manuscript. In his transcription of MK, the text of MK's folio 64-65, covering Hand.Ādur.Mār. $\int S_{S 3} 3^{-1} 54$, is collated with DP, whose readings are provided in red above 


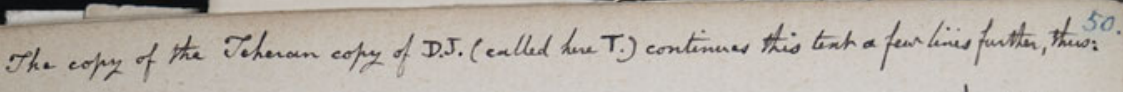

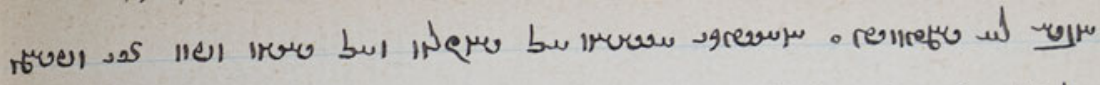

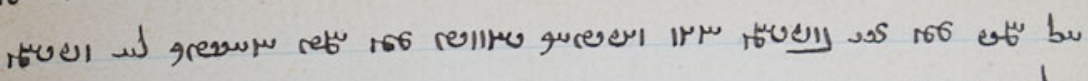

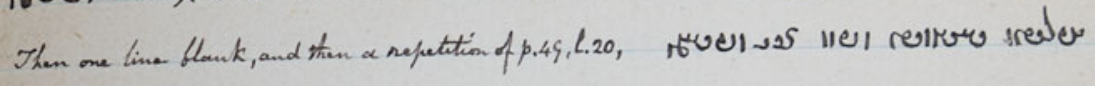

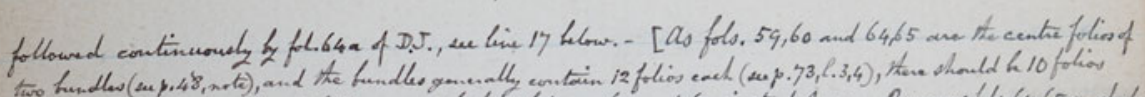

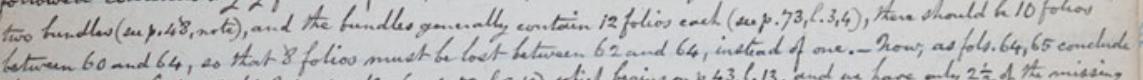

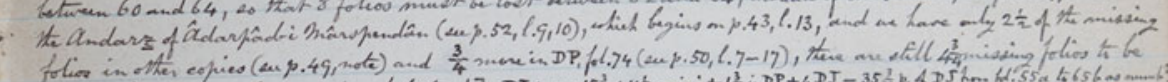

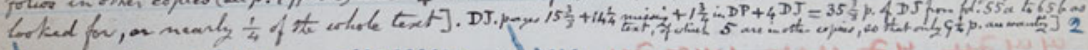

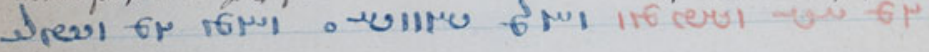

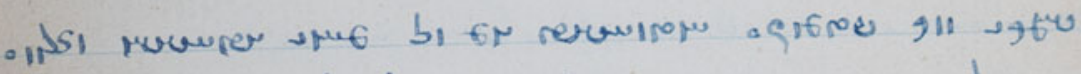

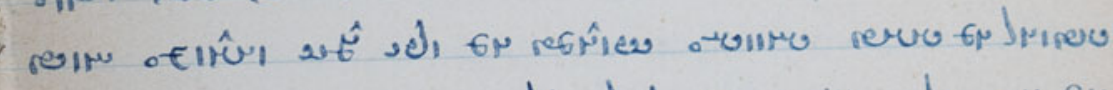

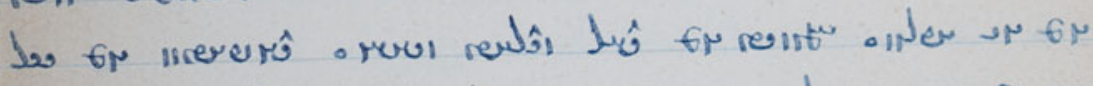

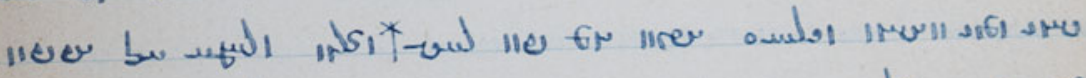

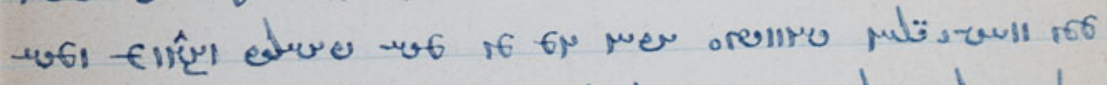

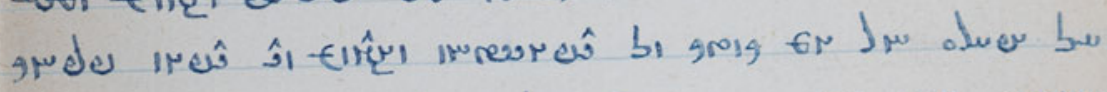

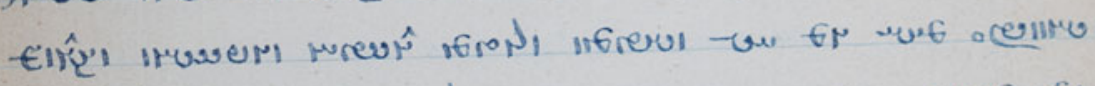

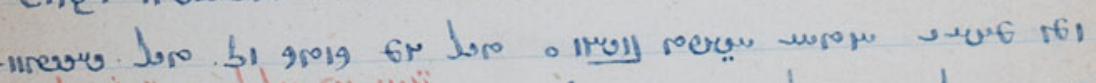

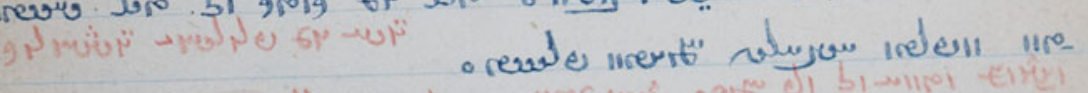

Jipin

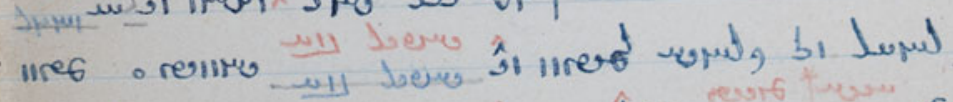

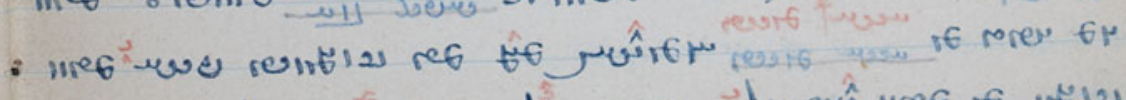

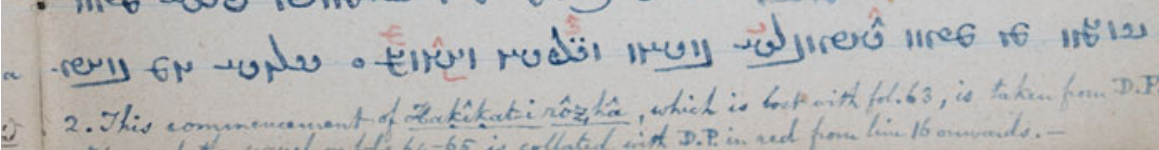

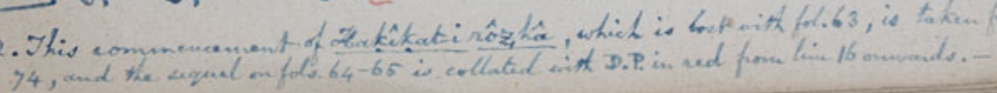

Figure 5. West, Notebook I3, p.5O showing the text of Handarz $\bar{\imath}$ anōšag-ruwān Ādurbād $\bar{\imath}$ Māraspandān (MK Text I2) SSII9-I32 transcribed from DP and lost in MK with folio 63.

the words of MK written in blue ink (West, Notebook I3, pp. 50-52). The Handarz $\bar{\imath}$ anōšag-ruwān $\bar{A} d u r b \bar{a} d$ ' Māraspandān ends at the bottom of MK's folio 65, but folio 66, on which a new text should have started, is lost. In his transcription in Notebook I3, West leaves the remainder of page 52 and the first six lines of p. 53 blank. He might have been hoping to be able to supply the text lost with MK's folio 66 from another manuscript, but unfortunately these lines in his Notebook I3 have remained blank. JamaspĀsāna I9I3, 
p. 77 supplies some of the text of MK's lost folio 66 from other manuscripts. The text lost in MK on fol. 66 was possibly all of Mādayān $\bar{\imath}$ sìh yazdān, and SSI-3 of an unspecified Fragment, retrieved by JamaspĀsāna I9I3, p. 72 from the ms. TDa. In August I 87I West copied the Mādayān $\bar{\imath}$ sīh yazdān in Notebook 3, I24-I26 from M6 (Cod.Zend 5I) of Martin Haug's collection, the manuscript which was written by the grandson of the scribe of DP mentioned above, and collated the end of this text with DP fol. 74rio-77v, supplying text missing in M6 from DP.

\section{Concluding Remarks}

A close investigation of West's transcription of texts preserved in the Pahlavi codex MK shows the extent to which his work informed the editorial work of Dastur Jāmāspji. On numerous occasions, readings edited by JamaspĀsāna I9I 3 are in fact not those of the ms. MK but result from emendations made by West in his transcription of I 875 , where he usually supplied, in pencil and by conjecture, words which are missing in MK due to damage to the manuscript. Usually West was later able to confirm or correct his restorations by collating other manuscripts, in particular the ms. T (Dastur Jāmāspji's copy of the manuscript JJ). In the case of the Handarz $\bar{\imath}$ anōšag-ruwān $\bar{A} d u r b \bar{a} d \bar{\imath}$ Māraspandān in Notebook I3, pp. 43-5I, where at the top of the folios of MK four lines are lost due to physical damage to the codex, he filled most of the gaps with readings, marked in pencil, "from a copy of Hi6 and Hi7" (Notebook I3, p. 43 bottom) except for the end, which he collated with DP. Almost all of West's restorations have entered JamaspĀsānā's edition of I9I3, many of them unmarked. Shortly before his death West is reported to have said with characteristic understatement that "although his studies and researches had always been undertaken for the sake of amusement and curiosity, they could hardly be considered as mere waste of time". ${ }^{27}$ In fact, they have long come to be regarded as a milestone, and his Notebooks reveal that his contributions to Pahlavi studies are even greater than hitherto thought.

\section{References}

Agostini, D. 20I3. Ayādgār $\bar{\imath}$ Jāmāspīg. Un texte eschatologique zoroastrien. Roma: Pontifical Biblical Institute (Biblica et Orientalia 50).

Anklesaria, Behramgore Tahmuras 1913. Introduction. In: J. M. JamaspĀsāna, The Pahlavi Texts

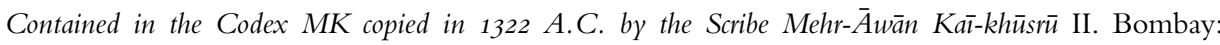
Fort Printing Press, pp. I-62.

Antia, Edulji Kershaspji I900. Kārnāmak-i Artakhshìr Pāpakān. The Original Pahlavi Text, with transliteration in Awesta characters, translation into English and Gujārati and selections from the Shāhnāmeh, Bombay.

Bartholomae, Christian I9I5. Die Zendhandschriften der K. Hof- und Staatsbibliothek in München. München: In Kommission der Palm'schen Hofbuchhandlung.

de Blois, François 2000. A Persian poem lamenting the Arab conquest. In: Carole Hillenbrand (ed.),

Sudies in Honour of Clifford Edmund Bosworth. Vol.II: The Sultan's Turret: Studies in Persian and Turkish Culture. Leiden, Boston and Köln: Brill, pp. 82-95.

Geldner, Karl Friedrich I896. Avesta. The Sacred Books of the Parsis. Vol.I, Stuttgart: Kohlhammer.

${ }^{27}$ Jackson 2004, p. 2. 
Haug, Martin I 862. Essays on the Sacred Language, Writings, and Religion of the Parsees. Bombay: Bombay Gazette Press.

Haug, Martin I 878. Essays on the Sacred Language, Writings, and Religion of the Parsis. Second edition edited by E.W. West. London: Trübner \& Co.

Haug, Martin and Edward William West I872. The Book of Arda Viraf. The Pahlavi text prepared by Destur Hoshangji Jamaspji Asa, revised and collated with further mss., with an English translation and introduction and an appendix containing the texts and translations of the Gosht-Fryano, and Hadokht-Nask. Bombay: Government Central Book Depot \& London: Trübner \& Co.

Jackson, Abraham V.W., revised by J. B. Katz 2004. West, Edward William (I824-I905). Oxford Dictionary of National Biography (online ed.). Oxford University Press. http://www.oxforddnb. com/view/Io. I093/ref:odnb/9780I986I4I28.00I.oooI/odnb-9780I986I4I28-e-36836, accessed Is Sept. 2018.

JamaspĀsāna, Jamaspji Minocheherji I9I3. The Pahlavi Texts Contained in the Codex MK copied in 1322

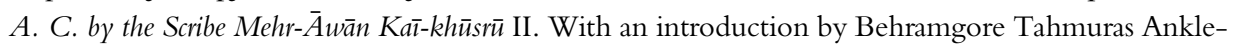
saria. Bombay: Fort Printing Press.

Menasce, Jean de I950. A Provisional Handlist of the Late E. W. West's Papers Preserved in the Library of the Royal Asiatic Society. Journal of the Royal Asiatic Society of Great Britain and Ireland, I, pp. 53-63.

Sanjana, Darab Peshotan i896. The Kârnâmê î Artakhshîr $\hat{\imath}$ Pâpakân, being the oldest surviving records of the Zoroastrian emperor Ardashîr Bâbakân, the founder of the Sâsânian dynasty in Irân. Bombay: Education Society's Steam Press, Byculla.

Sanjana, Peshotan Behram I885. Ganjeshāyagān, andarze ātrepāt mārāspandān, mādigāne chatrang, and andarze khusroe kavātān. The original Péhlvi text, the same transliterated in Zend characters and translated into the Gujarati and English Languages; a commentary and a glossary of selected words. Bombay: Duftur Ashkara Press.

Sheffield, Daniel 2009. Annotations of Selected Manuscripts from the K. R. Cama Oriental Institute. Completed in Mumbai January-June 2009. Unpublished typescript.

West, Edward William I880-I897. The Pahlavi Texts. 5 parts, Oxford: OUP (Sacred Books of the East Vol. 5, pp. I 8, 24, 37, 46).

West, Edward William I 887. Notes sur quelques petits textes Pehlevis. Le Muséon 6, 263-272.

West, Edward William I896-I904. Pahlavi Literature. In: W. Geiger and E. Kuhn (eds.), Grundriss der iranischen Philologie. Strassburg: Trübner, Vol. II, pp. 75-I29.

West, Edward William I904. The Pahlavi Jamasp-Nāmak. In: Avesta, Pahlavi and Ancient Persian Studies in Honour of the late Shams-Ul-Ulama Dastur Peshotanji Behramji Sanjana, M.A., PhD. Strassburg: Karl J. Trübner; Leipzig: Otto Harrassowitz, pp. 97-I I6.

Almut Hintze

SOAS, University of London ah69@soas.ac.uk 